\title{
Resilience as a Basis for Psychological Safety of Students with Disabilities
}

\author{
Vinogradova N.I. \\ TRANS-Baikal State University \\ Chita, Russia \\ vin57@list.ru
}

\author{
Kohan S.T. \\ TRANS-Baikal State University \\ Chita, Russia \\ ispsmed@mail.ru
}

\begin{abstract}
The article analyzes the causes of reduced psychological safety of students with disabilities. Under psychological safety of students is a condition characterized by perception and assessment of the University educational environment hazard, awareness of oneself as a future professional in the assessment of their informational and cognitive competence level, experiences of problematic situations of professionalization overcoming, the prediction of risk factors for disorders of self-health psychophysiological parameters, creating a sustainable learning and professional relations with all actors of the educational environment.

Resilience of students with disabilities acts as the central education of psychological security, helping the student to overcome difficult situations in the process of professionalization, to be responsible for the quality of entry into the profession, to be flexible to any changes in the educational environment in modern innovative conditions of higher education and changing professional standards.

The article presents data proving that high rates of emotional tension, close to stress, lead to a decrease in the quality of first-year students vitality personal level indicators. This causes a low involvement of students in the process of productive professionalization. At the same time, low rates of involvement lead to impoverishment of the information and psychological basis of professional competence. The causal dependence of risktaking low qualitative indicators by future specialists on poorly formed information and cognitive competence is revealed.
\end{abstract}

Keywords - psychological safety of students with disabilities; resilience of students, productive professionalization; components of health-saving method of professionalization.

\section{I.NTRODUCTION}

All over the world, including modern Russia, the number of students with disabilities is increasing. Already, more than 65 percent of the total contingent of students have chronic diseases, gradually leading to disability in adulthood [9]. Sociologists note the importance of analyzing all kinds of anomalies that occur in modern youth, which in the future will make changes in the rules of public life organization [22]. Negative trends in the development of the biosphere as a whole gradually change students ' ideas about the quality and duration of their own life in adulthood [17]. This changes their attitude to the training process. Psychological instability of modern students raises the question of ensuring their psychological safety in the educational environment of the University. Disabled people and students with disabilities form a special situation of professional development, burdened by their physical and psychological problems. Frequent appeals of such students to the psychological services of universities, as well as a significant number of deductions after each semester of study, especially in the first year, indicate the real facts of violation of their psychological safety. Ensuring the psychological security of the student's personality with health limitations is a real task, the solution of which creates prerequisites for positive socialization in the future. This condition is characterized by the perception and evaluation of the University educational environment danger, awareness of oneself as a future professional in the assessment of the level of its informational - psychological competence, experience of overcoming of problematic situations of professionalization, the prediction of risk factors for disorders of psychophysiological parameters of their own health. The possibility of establishing sustainable educational and professional relations with all subjects of the educational environment.

Therefore, we consider it important to identify those indicators of students with disabilities vitality that have an impact on the formation of the individual psychological security.

\section{LITERATURE REVIEW}

In modern studies, psychological security is analyzed as a result of the educational (external) and personal (internal) environments interaction [8]. Psychological safety with emphasis on individual psychological characteristics of personality A. Maslow highlighted as a core feature of the personality as the need for security [20]. The concept of "psychological security" is considered by researchers as the person's attitude to different aspects of reality and people [4], as a condition of human existence, a condition of security, an adequate basis of social behavior and subjective relationship to the world itself, the ability to overcome difficulties $[2,6,7,8]$. In general, scientists state that psychological security is a state that is determined by the perception and assessment of the environment in which a person is (the ability to find 
help, experience in overcoming problem situations, awareness of risk factors, the ability to meet the need for communication, the assessment of the degree of possibility of self-overcoming emerging problems [3,14].

In our opinion, the basic personality-driven component of psychological security is resilience, which provides productive human behavior in difficult life circumstances (M. bleyer, E. Werner, N. Garmesi, I. Gottesman, E. Masten, L. B. Murphy, M. Rutter, etc.). The study of the viability phenomenon is now at the peak of its relevance. Approaches to its study are deepening and expanding in connection with the changing negative circumstances of the human activity biological indicators gradual degradation [7,10,11,12,15,24]. Modern researchers agree that viability is an integrative core component of psychological security (A. I. Laktionova, A.V. Makhnach, A. A. Nesterova, E. A. Rylskaya, A.V. Shekhorina, A. M. Shcherbakova, etc.).

The problem of the study: to find out whether there are differences in the indicators of students with disabilities vitality in the first year and undergraduate graduates, as well as how the educational environment of the University is able to improve the psychological safety of such students.

\section{RESEARCH METHODOLOGY}

The article implements the most important methodological principles of Russian psychology: the principle of determinism (S. L. Rubinstein, A. N. Leontiev), the principle of unity of man and the environment (M. I. Sechenov), the principle of consistency (B. F. Lomov). The theoretical basis of the study was: - ideas about psychological safety in the educational environment (I. A. Baeva, Yu. P. Zinchenko, N. S. Efimova, V. V. Rubtsov); - concepts of human viability (J. K. Ionescu, S. K. Kelett-Kobaza, A. I. Laktionova, A.V. Makhnach, A. A. Nesterova, E. A. Rylskaya, N. M.)

The study was conducted on the basis of Transbaikal state University. The sample consisted of 62 students with special needs and disabilities enrolled in different faculties of Sabga. Of these, 32 are freshmen and 30 are undergraduate students. The average age of the subjects was 17-22 years. Research methods: theoretical methods: analysis and generalization of literature on the topic of research. Empirical method: testing. The method is implemented using the following techniques: 1, MMPI Technique. 2. Test of resilience D. A. Leontiev, E. I. Rasskazova. Method of mathematical data processing: criterion $\varphi^{*}$ - Fisher angular transformation (Fisher criterion).

\section{RESULTS}

At the applied level, the study may be of interest to employees of higher education psychological services. This work can serve as a justification for the students with disabilities psychological safety psychological support special programs, the development of technologies for their training, taking into account the indicators of resilience.

We consider the psychological safety of students with disabilities as this condition, which is characterized by the perception and evaluation of the University educational environment danger, awareness of oneself as a future professional in the assessment of the informational psychological competence level, experience of professionalization problematic situations overcoming, the prediction of risk factors for disorders of psychophysiological parameters of their own health. The possibility of establishing sustainable educational and professional relations with all subjects of the educational environment.

The resilience of students with disabilities acts as the Central education of its psychological security, helping to overcome difficult situations in the process of professionalization, to be responsible for the quality of entry into the profession, to be flexible to any changes in the educational environment in modern innovative conditions of higher education and changing professional standards. In this regard, we determine the quality of psychological security in terms of students ' resilience.

The MMPI personality questionnaire was used to study the mental level of students resilience with disabilities. This technique has a wide range of applications, we are also interested in identifying with its help the profile levels characterizing the current emotional state of the subjects and indicators of the fluid resistance mental level.

The results of MMPI profiles are shown in table I.

TABLE I. THE NUMBER OF PEOPLE (IN \%) ON THE PROFILE OF MMPI

\begin{tabular}{|c|c|c|}
\hline MMPI profile level & $\begin{array}{c}\% \text { and number of } \\
\text { people }(100 \%-32 \\
\text { people) }\end{array}$ & $\begin{array}{c}\% \text { and number of people } \\
(100 \%-30 \text { people })\end{array}$ \\
\hline $\begin{array}{c}\text { Normal (most of the } \\
\text { indicators are in the range } \\
\text { of 40-60T) }\end{array}$ & 21,3 & 78,3 \\
\hline $\begin{array}{c}\text { Recessed (most of the } \\
\text { indicators are below 50 T, } \\
\text { the values of F-low, K- } \\
\text { high) }\end{array}$ & 14,8 & 5 \\
\hline $\begin{array}{c}\text { Boundary (most of the } \\
\text { indicators are above 60T } \\
\text { and a significant-above } \\
\text { 70T, the value of F-high, } \\
\text { K-low) }\end{array}$ & 35,8 & 16,7 \\
\hline $\begin{array}{c}\text { intermediate (equal } \\
\text { number of indicators of } \\
\text { normal and boundary } \\
\text { profiles) }\end{array}$ & 19 & \\
\hline
\end{tabular}

$78.3 \%$ of graduates have a normal profile, which indicates that they have a resource to overcome the difficulties of professionalization. In freshmen only $(31.1 \%)$ demonstrate the norm for this profile. Borderline profile was revealed in $16.7 \%$ of 4 th year students and $25.8 \%$ of 1 st year students, which indicates that a quarter of 1 st year students respondents are in high emotional tension. The intermediate profile was found only in young people enrolled in the 1st year. It indicates a decrease in mental activity. This can be explained 
by the stress caused by uncertainty and fear of overcoming the problems of professionalization after familiarization with the requirements of the professional standard. Data on the normal profile differ in favor of year 4 students (FEMP. $=2.069$ at $p=$ $\leq 0.05)$. This means that the difficulties encountered on the path of life, most undergraduates do not cause great shocks and stresses. It can be considered that the educational environment of the University has a significant impact on the mental level of graduates vitality.

The study on the personal (social level) vitality was carried out with the help of the vitality test D. A. Leontiev, E. I. Rasskazova. The test identifies the overall measure of resilience and its components: engagement, control and risktaking.

The results of the study are shown in table II.

\begin{tabular}{|c|c|c|c|c|c|c|c|c|}
\hline \multirow{2}{*}{$\begin{array}{l}\text { The } \\
\text { indicators } \\
\text { of } \\
\text { resilience } \\
\text { /scale }\end{array}$} & \multicolumn{2}{|c|}{ the viability } & \multicolumn{2}{|c|}{ involvement } & \multicolumn{2}{|c|}{ Control } & \multicolumn{2}{|c|}{ risk taking } \\
\hline & 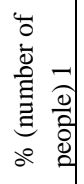 & 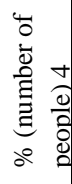 & 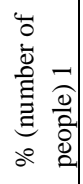 & 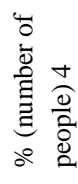 & 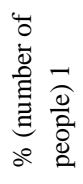 & 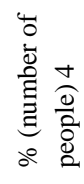 & 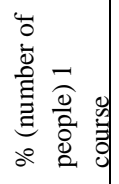 & 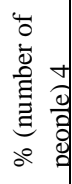 \\
\hline $\begin{array}{l}\text { Above the } \\
\text { average }\end{array}$ & 17,1 & 21 & 14 & 26,3 & 23,3 & 25,9 & 14 & $\begin{array}{c}38 \\
3\end{array}$ \\
\hline $\begin{array}{l}\text { Average } \\
\text { level } \\
\text { (norm) }\end{array}$ & 38,4 & $\begin{array}{c}66, \\
1\end{array}$ & 34,8 & 71,7 & 50 & 71,7 & 30,6 & 55 \\
\hline $\begin{array}{l}\text { Below } \\
\text { average }\end{array}$ & 48,1 & 4,9 & 51,2 & 5 & 26,7 & 3,2 & 66,4 & 6,7 \\
\hline
\end{tabular}

Data Table II indicate a significant difference in the severity of the "involvement" indicator in two groups of students. It can be concluded that in students with disabilities in the first year communicative skills are not formed, which limits the possibility of trusting, full communication with classmates. An unformed sense of support from fellow students is an indicator of reduced psychological security. Inadequate perception of the image "I am a future professional" is due to the fact that most often such students choose the profile of future professional training focusing on the opinion of relatives, on the idea of the University building proximity to the place of residence, etc. This indicates the poverty of the psychological security internal resource. Comparison of the indicator "control" expression degree in the structure of vitality in students of 1 and 4 courses shows that half of the first-year students demonstrate an average level of control. This means that they, in general, are able to objectively assess their own ability to control the educational situation, taking into account the problems of their own health. However, students do not show high volitional regulation of behavior. This is a consequence of their emotional distress, identified at the mental level of resilience. Distrust of all subjects of the educational environment is clearly manifested. It can be stated that the indicator of control to a greater extent regulates the resilience of students with disabilities in the first year than the indicator of involvement. The inconsistency of these indicators formation significantly reduces the quality of first-year students professionalization.

Data Table II demonstrate that the indicator "risk taking" is the most "sinking" in the structure of 1st year students resilience. It can be assumed that often underestimated inadequate self-assessment of cognitive capabilities disorientates students in the analysis of the entire "fan of opportunities" for solving educational and professional tasks presented in the adapted work programs for disciplines. They are guided in advance by the easiest way to solve professional problems, which generates passivity and unwillingness to act in conditions of uncertainty. The basis of psychological unpreparedness for reasonable risk in choosing a "healthsaving" method of such students professionalization is: unwillingness to take responsibility for the quality of the process and the result of professional training, lack of the productive professionalization process essence and dominants understanding. Productive professionalization of students with disabilities we call " health-saving way of mastering the specialty, providing psychophysiological and psychological security. It is provided by: the ability to overcome psychological barriers of professional communication; formed skills of forecasting the impact of professionalization methods and dynamics on the quality of their disease, making responsible decisions in an uncertain educational situation. In addition, some negative personal qualities of students with disabilities, caused by the peculiarities of the disease and general unwillingness of society to understand and accept such people, strengthen the indicators of unwillingness to take risks, and indicators of low responsibility for the results of professionalization.

\section{V.DISCUSSION}

In our opinion, the gradual improvement of the students with disabilities vitality indicators from the 1st to the 4th year, and, consequently, the increase in the quality of their psychological security is due to the implementation by the specialists of the regional center for inclusive education of the psychological security forming program Zabgu. Within the framework of this program, the activities of all subjects of the University educational environment (volunteers, teachers, parents of students) are consolidated to gradually create conditions conducive to the formation of students ' resilience. The targets of influence revealed by us provide formation of " health saving option of psychological safety.

\section{VI.CONCLUSION}

It can be stated that, revealed at the mental level of vitality, high indicators of emotional tension, close to stress, lead to a decrease in the quality of vitality personal level indicators. This is evidenced by the indicators of students' low involvement in the process of productive professionalization. At the same time, low rates of involvement lead to impoverishment of the information and psychological basis of professional competence. The causal dependence of low qualitative indicators of risk-taking by future specialists on poorly formed information and psychological competence is revealed. The analysis of table 2 data shows that the 
[25] Alexsandr S. Kuznetsov. Russian Professor's meeting. Russian Journal of Physical Education and Sport. 2019, 14(1), pp. 17-22. DOI: 10.14526/2070-4798-2019-14-1-18-24

psychological safety of first-year students with disabilities has significant violations. At the same time, the indicators of students psychological safety in the final year tend to stabilize.

\section{References}

[1] Ananyev B.G. On the problems of modern human knowledge. SPb. Peter. 2001, 264.

[2] Baeva I.A. Providing psychological security in an educational institution. St. Petersburg: Speech. 2006, 278.

[3] Bessonova T.A. To the question of ensuring information and psychological security of students Text. Izvestia TRTU. Thematic issue "Psychology and pedagogy". Taganrog: TRTU. 2006, 13(68), pp. 311316.

[4] Galazhinsky E.V., Ryl'skaya E.A. System dynamics approach to the study of the viability of the person. Tomsk State University Bulletin. 2010, 338, pp. 169-173

[5] Efimova N.S. Professional safety as a psychological and pedagogical problem of training of specialists. Scientific and Technical SPbSPU Statements. Humanities and social Sciences. SPb. 2011, 4, pp. 145-149.

[6] Maknach A.V. The viability of a person: individual, professional and social aspects. M.: Publishing house "Institute of psychology RAS". 2016, 509.

[7] Zeer E.F., Socio-psychological aspects of the development of vitality and formation of human resilience. Pedagogical education in Russia. 2015, 8 .

[8] V.P. Zinchenko. Psychological security of the individual and society in the modern information space. 1995, 64.

[9] Krasnianskaya T.M. Psychological preparation for personal safety in extreme situations. Pyatigorsk: PGLU. 2010, 268.

[10] Laktionova A.I. Human Viability: a metacognitive approach. Human Viability: individual, professional and social aspects. Moscow: Institute of psychology RAS. 2016, pp. 88-110.

[11] Nesterova A.A. Socio-psychological approach to understanding the construct "viability of personality". Human Viability: individual, professional and social aspects. M.: Publishing house "Institute of psychology RAS". 2016, pp. 49-59.

[12] Rylskaya E.A. Psychology of human viability. Doctor's thesis. Yaroslavl. 2014, 446.

[13] Pimonova C.B. Development of creative potential of students in conditions of safe educational environment. Candidate's thesis. Stavropol. 2006, 151.

[14] Roshchin S.K. Some issues of information and psychological security of Russian society. Problems of information-psychological security: collection of articles and materials proc. Moscow. 2016, pp. 27.

[15] Shvareva E.V. Resilience as a psychological characteristic of participants in the modern educational environment. Pedagogical education in Russia. 2011, 4.

[16] Burgess S. Lithium for maintenance treatment of mood disorders. Br. J Psychiatry Cochrane Datebase Syst rev.2001, 3. URL: https://www.healthyplace.com/bipolar-disorder/articles/lithium-formaintenance-treatment-of-mood-disorders

[17] Nowak G. Zinc, future mono/adjunctive therapy for deresion: Mechanisms of antidepressant action. Pharmacol Rep. 2015, 67 (3), pp. 659-62. URL: https://www.healthyplace.com/bipolardisorder/articles/lithium-for-maintenance-treatment-of-mood-disorders

[18] Bandura A. Self-efficacy: toward a unifying of behavior change. Psychological review. 1997, vol. 84, pp. 191-215.

[19] Edmondson A. Psychological safety and learning behavior in work teams. ABI/INFORM Global. 1999, 350.

[20] Maslow A. Self-actualizing and Beyond. Challenges of Humanistic Psychology. N.Y. 1967, 256.

[21] O'Neill P. Experts: Inner Chaos Fuels Kids Who Kill. The Oregonian. May 25, 1998, A13.

[22] Rossman S., Morley E. Introduction. Education and Urban Society. 1996, 28(4), pp. 395-411.

[23] Sprague J., Sugai G., Walker H. Antisocial Behavior in Schools. Handbook of Child Behavior Therapy. N.Y. 1998, pp.451-474.

[24] Staw B. M., Lance E. Sandelands, Jane E. Dutton. Threat-rigidity effects in organizational behavior: A multilevel analysis. Administrative Science Quarterly. 1981, 26, pp. 501-524.
[26] Stocols D. Environmental psychology. An. Ref. Psychology. 1978, 29, pp. 253-295. 